\title{
鶏の慢性呼吸器病 $(\mathrm{CRD})$ に関する研究*
}

I. 野外例拉よび実験的感染例の臨床 - 病理学的所見

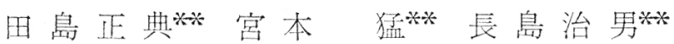

鵎の慢性呼吸器病 Chronic Respiratory Disease (略して CRD と呼ばれる) は，1943 年 Dilaplane and STUART1) により, アメリカではじめて記載された 病気である。本病はその台が示すよ5に, 呼吸器系を主 として侵可慢性疾患で, 臨㕅的には鼻漏, 流涙, 七キ, クシャミ, 顔面の腫脹, 咽喉部の粘液增量叔よび呼吸性 雑音党主徵とし, 病理㑇剖的には呼吸器症状の基礎とな る鼻腔，下眼營洞，喉頭，気管，気管支，肺沶よび気囊 の炎症性変化の汪か, 線維素性肝包膜炎和よび心霆炎の 存在が目をひく、潜伏期が長く，発生稊群汇打ける伝播 速度は緩徐であり，致命率は時に $75 \%$ にも達与ること があるといわれるが (MARTINEZ2)), 多くの場合, 10〜 30\% に止束るようである (Johnson 3)4); Cover and

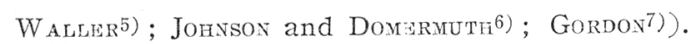

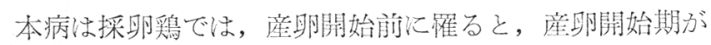
遅れ, 成謟では産卵の減少ない乙停止を起し, 肉鵴で はその成長を著しく阻害し, 宫た屠殺时に広籁な気囊病 変のために廃率部分を多くするなどにより, 善謟業者に 著しい妿威总与光る。現在で快各国から, その発生が瓡 告されているが，とくにアメリカとカナダでは広く伝播 乙, 地方病性に流行し,ニューカッスル病执よび伝染性気

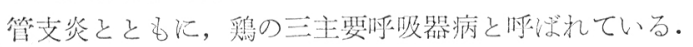
White-Stevers and $Z_{\text {EIBre }}{ }^{8)}$ によれば, 本病によるア メリカの年間の損害は，実に1億弗に達すると推定され ている。なお CRD は FAHEY) によりアヒルにおける 発生吕報告されておう，七面鳥の伝染性下眼简洞炎 Infectious sinusitis とも, 後に詳しく述べるよ5に, 原

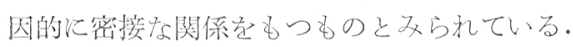

私どもは1956年 3 月以降東京都下, 4 月以降大陃府下

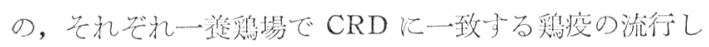
ていることを確認した。目下なお病理学的並びに病因学 的研究を継続中であるが，今回は現在屯でに得られた所 見の一部学取宗とめて献告し, 参考に资したいと思う。

\section{I. 野外例所見}

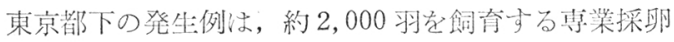
䍩鵎場に文られた。初発は1953年で, 初年度は50日羅

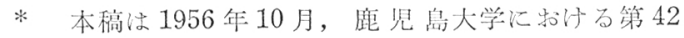
回日本獣医学会で演述された

** 日本生物科学研究所
}

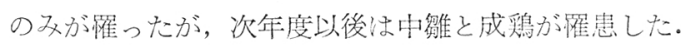
大阪府下の発生例子また，專業採卵荃謟場に2られ

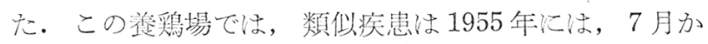
ら11月にいたる期間に発生し，1956 年度は 4 月以後 5 カ月雛を祘かした。

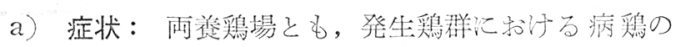
発生は散発的であった。薙の場合の主要症状は, 番漏, 流涙, クシャミ, 七キ, 呼吸性雑咅, 気道の粘液を排除 せんとナるような頙部起振る動作，顔面の腫脹などであ り, 元気と食欲の減退学伴い, 次第飞瘦せ, 発育は著し く遅れ, から不揃いになった。致命率怔正確に調榃され なかったが，東京都下例では数\%に止束り，大阪府下例 では駄熖として御汰されたもの学も含めると約 $30 \%$ に 達した。

成鵎が䍜った時には，上記症状の活か，とくに下眼瓷 洞部の腫脹を呈するものが多く，この際いとうべき恵臭 学した（図 1). 病期的飞症状の推移を又ると，初期 には稀薄透明な貝汁学漏出子るが，次第飞濃厚粘稠とな

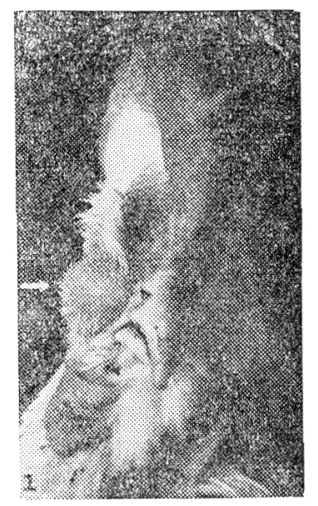

図 1-No.6. 右下腿漼洞部の胿 脹老示守(矢印).

b) 病理学的所見：丧 1 飞示与東京都下の 14 例, 大 防府下の 8 例, 棓 22 例が病理学的飞䧓べられた。年令

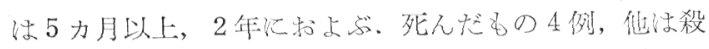
処分された。大限府下の8 例中，3例が死九でいるが，

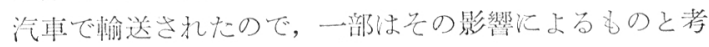
光られる。正確な絓過は不明であるが，原队学的拆究の 関係から，努めて初期症例と思われる女の菟集したに むかかわらず, 病理学的には亚急性ないし慢性の病变 
表 1 野外発生研究例一筧表

\begin{tabular}{|c|c|c|c|c|c|c|c|c|c|c|c|c|c|c|c|c|c|c|c|c|c|c|c|}
\hline \multicolumn{2}{|c|}{ 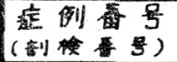 } & 11 & 2 & 3 & 4 & & 6 & 7 & & 7 & 10 & 16 & 12 & 13 & 14 & $\begin{array}{c}15 \\
10+8\end{array}$ & $\begin{array}{c}16 \\
(\operatorname{sic} 6)\end{array}$ & $\begin{array}{l}17 \\
\cos 9\end{array}$ & $\begin{array}{l}18 \\
13019\end{array}$ & $\begin{array}{l}19 \\
(3220) \mathrm{k}\end{array}$ & 20 & & \\
\hline 発 & 生 地 & 曼京 & 4 & 4 & . & ; & 4 & 4 & 4 & . & 4 & 4 & 5 & . & . & 大防 & . & " & - & 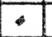 & 4 & 4 & . \\
\hline 品 & 種 & $\sin 2$ & 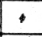 & 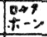 & ThZ大 & GLP & - & 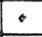 & 4 & $\bullet$ & - & . & - & - & - & - & 4 & 4 & . & 6 & 0 & 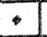 & 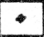 \\
\hline & 性 & $\hat{8}$ & 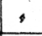 &.+ & 9 & $\hat{\gamma}$ & 8 & 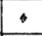 & - & 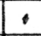 & - & & 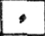 & 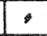 & - & - & $\cdot$ & & + & 4 & $\$$ & - & $\$$ \\
\hline 年 & 令 & 5月 & 4 & 3 & 1 年 & & 4 & 6 月 & 1 年 & 24 & 6月 & 4 & 14 & 7 月 & 9R & 58 & 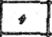 & & + & 8 月 & 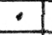 & - & $\cdot$ \\
\hline 赭 & 㽭 & $\bar{k}$ & - & • & 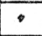 & $t$ & $\bar{k}$ & 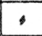 & & . & & 4 & 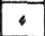 & 4 & 4 & 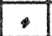 & . & - & $t$ & $\bar{k}$ & $T$ & $k$ & $T$ \\
\hline 縕䇾 & 化にdる坛分 & 要意 & 慢 & 勇跑 & 慢 & 意 & 慢 & 垔急 & 慢 & 1 & 殸 & - & 4 掼 & 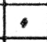 & - & 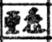 & 澘 & - & 4 & 程 & 题 & 愲 & 霹桑 \\
\hline & 瘦 & $t$ & + & + & + & + & $t$ & + & + & + & + & + & + & + & + & $t$ & $t$ & $t$ & + & + & + & + & - \\
\hline ד/ & 椊 & $t$ & - & - & $t$ & + & + & + & $t$ & - & - & - & $t$ & + & - & - & - & - & + & $t$ & $t$ & - & - \\
\hline 要 & 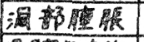 & - & - & - & + & + & + & + & + & + & + & - & + & + & - & - & - & - & $t$ & + & + & + & - \\
\hline & 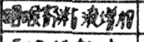 & $t$ & + & + & + & + & + & + & + & + & + & - & + & + & + & + & - & + & + & + & + & - & + \\
\hline & 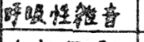 & + & + & + & $t$ & $?$ & + & $t$ & + & + & + & - & \pm & - & - & + & - & + & $?$ & + & $?$ & - & $?$ \\
\hline 站 & $<i \leqslant 7$ & + & + & + & $t$ & ? & + & + & $t$ & $t$ & + & + & + & + & - & $t$ & $t$ & + & $?$ & + & $?$ & $t$ & $?$ \\
\hline & te & $t$ & - & - & $t$ & $?$ & $t$ & - & 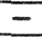 & $1+$ & $t$ & - & - & - & - & + & - & - & ? & + & $?$ & -1 & $?$ \\
\hline 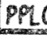 & 0 分被 & + & $t$ & 1 & + & 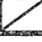 & + & - & - & 1 & + & + & + & $t$ & + & 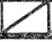 & $\sin$ & & & - & $f$ & + & + \\
\hline
\end{tabular}

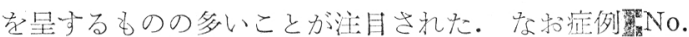
14 以症鵎場で発症発発見後，当所に移して 1 力月余に わたり観察を加光たものであるが，その間，明瞭な症状 を示し続けた。

主要症状の弓ら鼻汁漏出, 咽喉部の粘液增加和よびク シャミは大部分の症例飞頻発し，下腿简洞部の腫脹，呼 吸性雑音小よび流淚はそれ年れ約半数の症例に，七キは 症例の約 $1 / 3$ 亿観察された。

Pleuropneumonia-like organisms (PPLOと略称さ

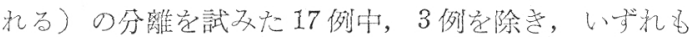
陽性成績去示した。両発生例のそれぞれ一部の症例につ いて，ニューカッスル病打よび伝染性気管支炎ウイルス に刘する中和抗体学調べたが，いずれも除性であった。

肉眼的変化：鼻腔，下腿筒洞，喉頭，気管などの上 部気道粘膜は潮紅出るいは带黄灰白色足呈し，明膫飞肥 表 2 野外例の呼吸器系に括忷る病変の分布

\begin{tabular}{|c|c|c|c|c|c|c|c|c|c|c|c|c|c|c|c|c|c|c|c|c|}
\hline 部壁 & & 2 & 3 & 4 & 5 & 6 & 7 & 8 & 1 & 1 & 1 & 13 & 16 & 15 & 16 & 17 & 18 & 19 & 202 & 2122 \\
\hline 踛 & + & & + & & & & & & & & & & & t & $t$ & t & + & +1 & +1 & +- \\
\hline 下盽要洞 & + & + & + & + & & & + & + & & & & + & & + & + & + & + & + & +1 & +- \\
\hline 斋 & + & + & + & + & & t & + & $t$ & 1 & & t & + & & + & - & t & + & + & -1 & +1 \\
\hline 管 & + & + & + & + & & + & + & - & . & & + & - & & + & - & + & + & + & - & + \\
\hline 主策管支 & + & + & - & + & & + & - & - & & & & & & $t$ & - & 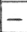 & - & - & & ++ \\
\hline 二次镻管支 & - & - & - & - & & - & - & & & & & & & + & - & - & - & - & - & $-t$ \\
\hline 三次盖管支 & - & - & - & -1. & & -1 & - & & & & & & & $1+$ & & $1-$ & - & - & $1-1-$ & $-1-$ \\
\hline & & & - & & & & & & & & & & & & & + & & + & & -+ \\
\hline
\end{tabular}

厚し，多量の灰白色ない乙带黄灰白色の粘秱液で被われ た。11例では下眼窝洞は，灰白色粘秱液むるいは黄色 チーズ様凝塊の多量を容れて拡張し，恶臭起放ち，壁の 著しい浮腫性あるいは線維性肥厚が認められた（図 2). 3例では鼻腔内にもチーズ様物が多られた。これらの变 化と関連乙て，眼結膜の潮紅，肥厚と絬膜囊内に滲出物 の潜溜を呈するものがしばしばあった。肺内気管支に炎 性变化を認めたものは４例で，弓ち1例は主および二次 罙管支腔内に，チーズ様化の傾们圶示与滲出物凝塊の多
量を充した。7例では胸， 腹，鎖骨間出るい镇気囊 に执いて，壁の肥厚溷濁が あり，霆内飞粘液膿性むる いは黄褐色チーズ㥞滲出物 の種及なる量を容れた。

他の臓器では, 成鷄に执 いて成熟卵胞の畉黄沪出 と, これ礼伴 5 腹膜炎学認 め，2 例に漿液性心囊炎か 又られた㳊か，特記ずべ 病变焉認如得なかった。

組織学的変化：検絮さ れた個々の症例，並びに时 吸器系各部に钼察された病

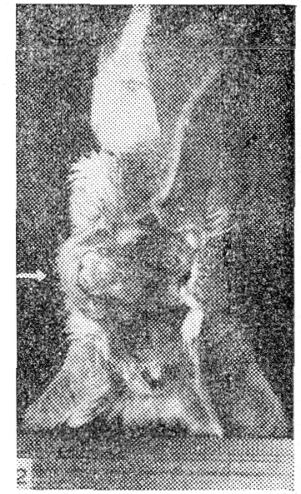

図 2-No.6. 堙脹部中心を通る 横断面. 洞内に多量のチーズ様济 出物凝塊定容れ，壁の線維性盵厚 高度(矢印)

変は, 疾病䋂過の長短に基くと考克られる差異安 除汗淁，多かれ少なかれ類似したものであった。

急性期にあると文られた7例で情，呼吸器系粘 膜の一般的变化として，上支細胞は織毛脱落，空 胞変性，核の種々なる退行性变化を示し，一部は 剩離した。分泌機能の九進が著明である。上文下 組織には充血, 浮腫が著しく, 时々出血がみられ, リンパ球，好酸球の游瞢性浸閵があった。

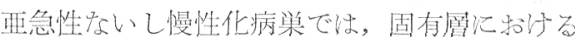

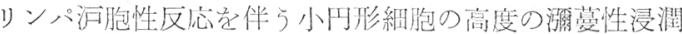
が最も目をひき，粘膜は正常鷄のそれの10 数倍の厚さ に達したものもあった。上艾細胞は隀大し，空胞变性に 陷るものも出るが，一方で法萎繀扁平化子著明であった (図 $3,4,5)$. 肉腿的汇チーズ様滲出物凝塊を容れた

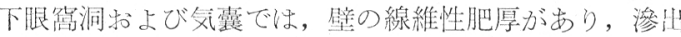
物凝塊に接して, 巨細胞の出現学伴う肉芽組織の新生が しばしば観察された（図 6)。肺内気管支腔に滲出物学 容れる場合飞も，気管支粘膜面加ら内腔へ向５幼若肉芽

日獣会誌 11 (1958) 


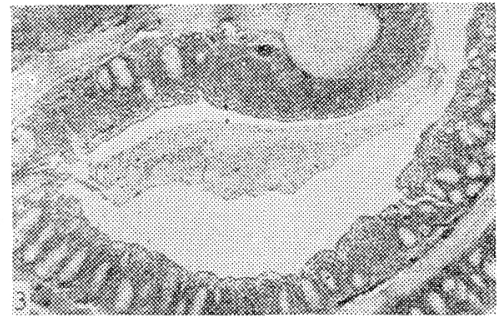

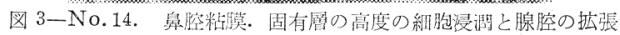

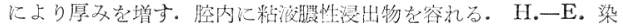
色, $\times 40$ 。

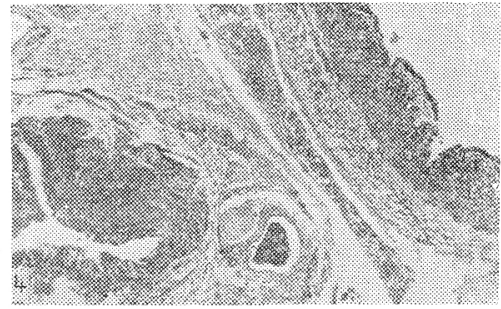

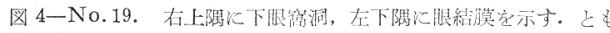

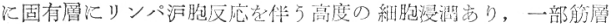
飞和上占. H. - E. 染色, $\times 40$

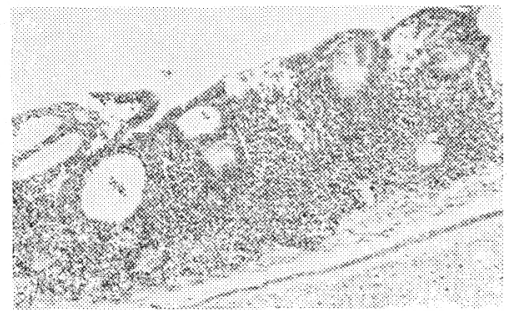

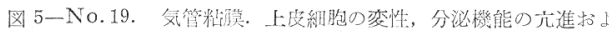

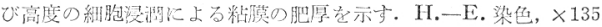

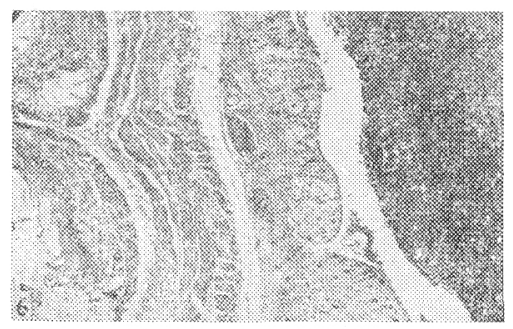

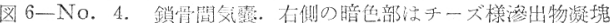

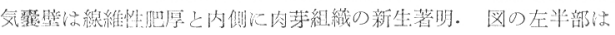
食道で另乃。 II. - E. 梁出, $\times 40$.

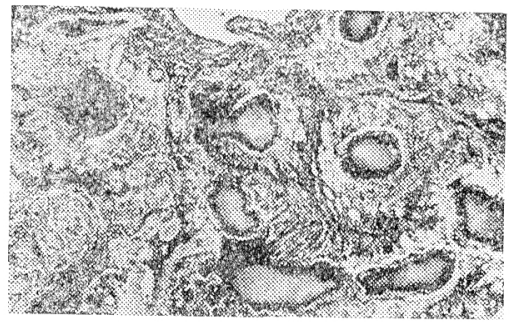

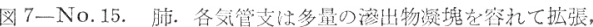

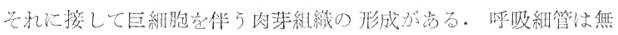
気性. H. - E. 测色, $\times 40$.

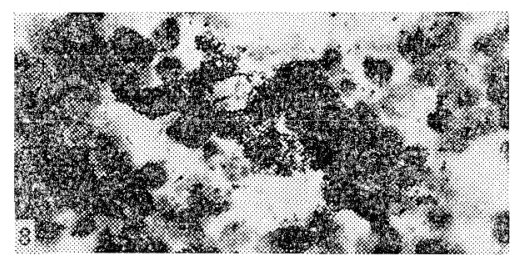

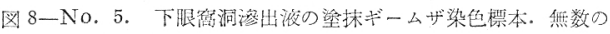
球菌榜微生物老㒛む。 $\times 1,200$ 。

組織の新生像がしばしばみられた。かかる場合，呼吸細 管以下は盉気性となること多く，通常，炎性変化法擎微 か，专るいはこ机学欠いた（図７），上部気道の渗出物を 塗抹し，ギームザ染色岕いいマキキャベロ染色を施す 々，直径1 4 以下の微小，球菌梯微生物の集簇が，主々 して細胞外性，一部細胞内性飞しばしば認められた（図 8).

要するに気道病変の性質恃, 慢性化の傾向の強いカタ

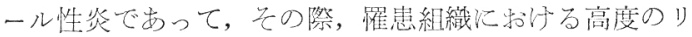
ンパ䋐状織の活性化を伴らこと学特徵とするものと理解

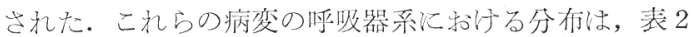

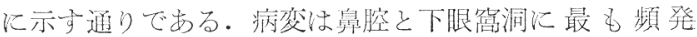
し，以下主気管支沈いたる上部気道化主として分布し， 二次気管支以下の侵五机西場合怯少小い。気雼炎は 8 例 (36\%) 灶六占机兄。

呼吸器系以外では眼絹膜飞, 性質飞扮いて, 呼吸器系

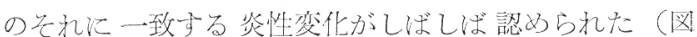

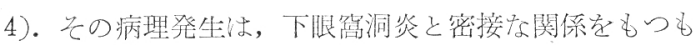

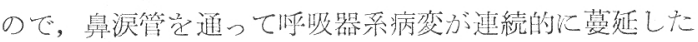
ものと考光られる。成謟で蛅床所見に一致して, 卵黄

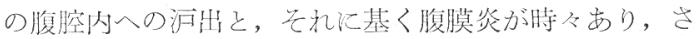

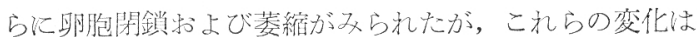
感染の全身的影響仙よる排卵機構の失調汇基くものであ

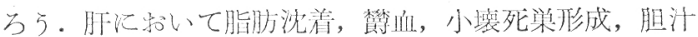

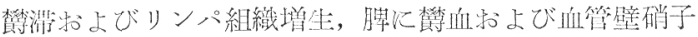
化，算の椤血とネフローゼ性変化，晹のカタール性炎， 上部消化管，とく飞口腔粘膜の小壞死栄ないし溃瘁形

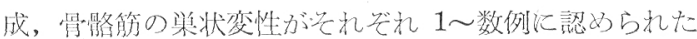
が，それら恋化の発現比性一貫性を久き，呼吸器系病变 との間飞特定の関係老見出し得なかった。

\section{II. 実験的感染例の所見}

検紊例からのPPLOの分誰は, 表1飞示した通りで

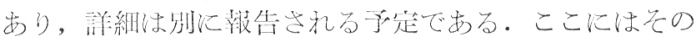

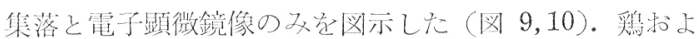

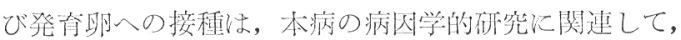
現在さらに広籁な実験が行われつつある。本瓡告では今 まで得られた成績の一部につき, 蹈床打よび病理学的 所見学中心として述べたい。

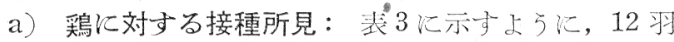
の絪の鼻腔，口蓋裂，下眼简洞出るい以父管内儿，野外 
表 3 実験的感染例一筧表

\begin{tabular}{|c|c|c|c|c|c|c|c|c|c|c|c|c|c|c|}
\hline \multirow{3}{*}{$\begin{array}{l}\text { 症例 } \\
\text { 厛号 }\end{array}$} & \multirow{3}{*}{$\begin{array}{l}\text { 年 } \\
\text { 今 }\end{array}$} & \multirow{3}{*}{$\begin{array}{l}\text { 接棰 } \\
\text { 材料 }\end{array}$} & \multirow{3}{*}{$\mid \begin{array}{l}\text { 接檩 } \\
16-k\end{array}$} & \multirow{3}{*}{$\begin{array}{l}\text { 潜 } \\
\text { 优 } \\
\text { 期 }\end{array}$} & \multirow{3}{*}{$\begin{array}{l}\text { 轱㷌 } \\
\text { (轻通) }\end{array}$} & \multicolumn{8}{|c|}{ 病变の余布 } & \multirow{3}{*}{ 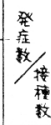 } \\
\hline & & & & & & 章 & 洞 & 唯 & & 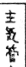 & 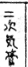 & 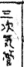 & & \\
\hline & & & & & & 胵 & & 㖽 & 管 & 支 & $\frac{1}{\mathbf{x}}$ & $\frac{d}{\frac{8}{2}}$ & & \\
\hline $\begin{array}{c}1 \\
(307)\end{array}$ & 5 月 & 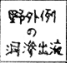 & 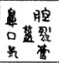 & $30 \mathrm{E}$ & $\begin{array}{c}k \\
(48)\end{array}$ & + & - & + & + & + & - & - & - & \\
\hline $\begin{array}{c}.2 \\
(30 \%)\end{array}$ & : & $"$ & " & , & , & $\frac{9}{6}$ & - & + & $t$ & + & - & - & - & \\
\hline $\begin{array}{c}3 \\
(319)\end{array}$ & : & 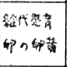 & $\begin{array}{l}\text { 洞 } \\
\text { 管 }\end{array}$ & 170 & $\left(\begin{array}{c}k \\
(2 \\
2\end{array}\right)$ & + & + & + & - & - & - & - & - & \\
\hline $\begin{array}{c}4 \\
(320) \\
\end{array}$ & 3 & , & . & 148 & $\left(\begin{array}{c}k \\
\left(10^{-}\right.\end{array}\right)$ & + & + & + & + & + & - & - & - & \\
\hline $\begin{array}{c}5 \\
(332)\end{array}$ & 87 & " & 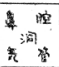 & $13 \mathrm{e}$ & $\begin{array}{c}k \\
(3-6)\end{array}$ & + & + & $t$ & + & - & - & - & - & $2 / 3$ \\
\hline
\end{tabular}

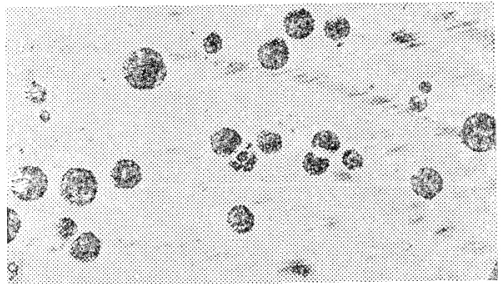

図 9-PPLO の集落. 中心部唯暗色で乳房状を是することが特

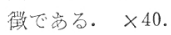

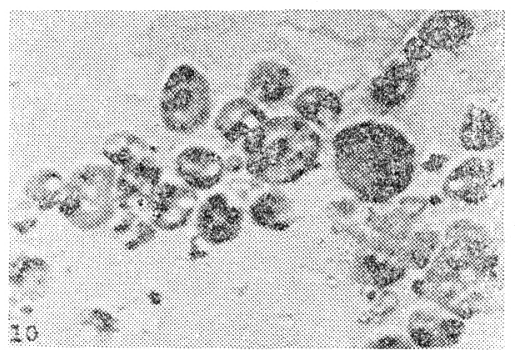

図 10-PPLO の電子顕微鏡写真. 直径 200-1, 000 m $/ 2$ の間に 出当のが大部分学占的る。 $\times 13,500$.

発生例の下眼简洞渗出液, あるい:継代発育畉の畉黄の

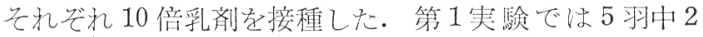
羽，第 2 奏験では 4 羽中 3 羽, 筹 3 夹験では 3 羽中 2 羽, 寸なおち全接程謟 12 羽中 7 羽が，最短 13 日，最長 30 日の潜伏期の後, 鼻漏, クシャミ, 咽喉部の粘液增加执 よび呼吸性雑音の症状を以て発病した。表示の5 例が， 症状発現後 2 10日で殺処分され病理学的に調ベられ た。

肉腿的並びた組織学的病変はともに, 鼻腔から主気管 支にいたる上部気道に分布し，2次気管支以下执よび気

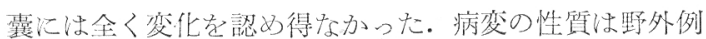

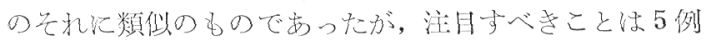

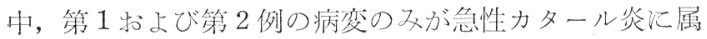
し，他の 3 例では粘膜固有層に批子る高度のリンパ沪胞 形成学伴う，緻密なリンパ球性細胞浸潤が特徽的であっ て，先の組織像はいずれも西急性炎と解すべきものであ った（図 11,12)。この5ち第 3 例恃第 2 病日，第 5 例

日獣会誌 11 (1958)
快第 3 病日に殺処分されたものであることに鑑み，かか 万呼吸器系病变は, 臨床的症状の発現前, 寸なわ喜い 潜伏期の間に徐々飞発達古るものと思われる。皇たこの

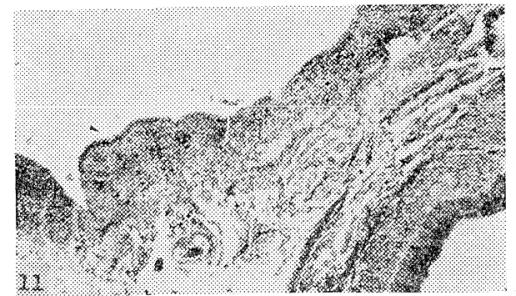

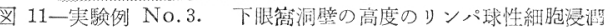
类示卞. H. -E. 染色, $\times 40$.

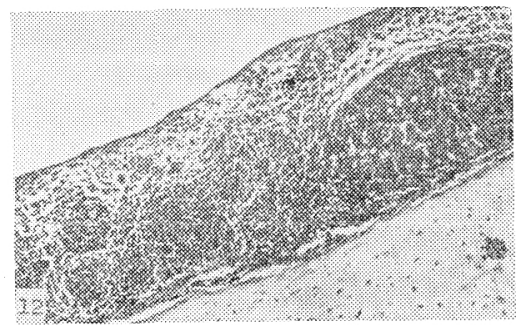

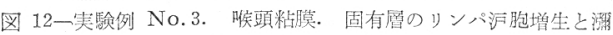

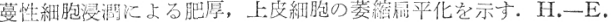
染色, $\times 135$.

事奏は, 呼吸器症状学欠きなが占, 病理学的に浮吸器 系化炎性变化を具光症例の存在与ること先示唆する。

b）発育卵に対する接種所見：私どもによって発育 卵飞分離されたPPLOは，7 日卵の䀦黄囊内に接種与 ると，接種後 24 時間目より㙞化時宗でにわたり不規則 に胎児を殺したが，大部分の胎児は接種後 5〜7 日の間 に死んだ。

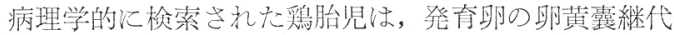
2 代の PPLO 老, 7 日卵の卵黄囊内接種し, 接種後 2日〜12日に死んだもの，出るいは殺されたもの38例で ある。

接種後 5 日以内に殺された胎児には，特記ずベき变化 を認得なかった。しかるに4 日以後の死例执よび 7 日 以後の殺例では，発育は一般に不良であり，いずれに拉 いて子肝，腎，中枢神経系，頭部，体壁，胎膜捻よび畉

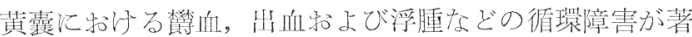

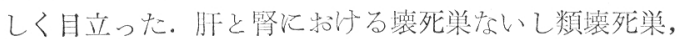

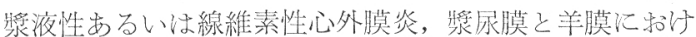
る上支細胞の軽度の栄状繁殖，中肧葉に扔引る主として 因管性飞出現与る円形細胞浸㵎，山るい:線維芽細胞の 增殖ない乙線維性肥厚がまれならず垫められた。これら の变化は瞬畉の後期にいたるに從い，次第に气の発現頻

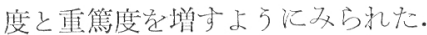

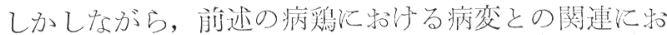
いて，最も注目された変化は呼吸器系の乞れであった。 気管，気管支招よざ肺内各気管支は，その腔が执張し， 


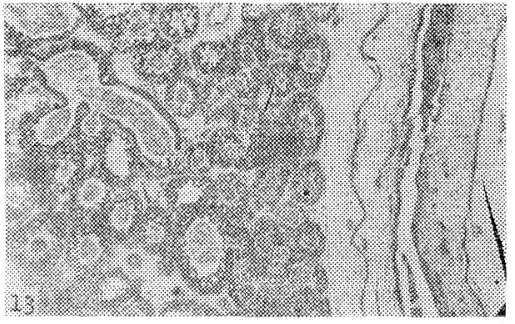

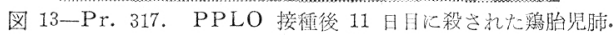

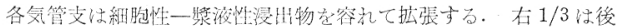

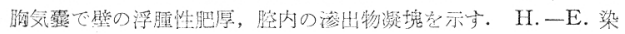
色, $\times 40$.

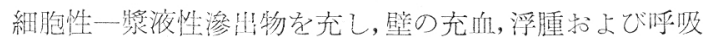

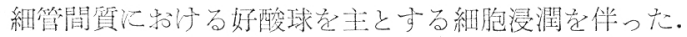

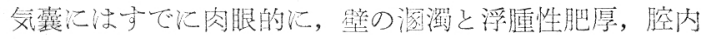
に打けるチーズ様滲円物の潜溜が認められた（図 13).

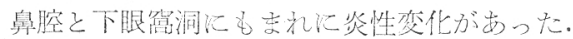

これらの呼吸器系病恋以, 捽種後の経過日数と密接な

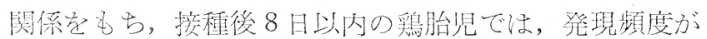

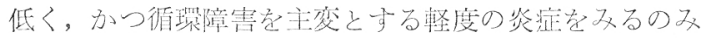
であった。9日以後のものでは, 検索された 12 例中, 8 例の呼吸器系の各部飞高度の病変が認められた。广拉 PPLO 感染胎睍にしばしば発現するといわれる, 関節 附近の膿瘍むるいはグラメローム形成は, 私どもの症例

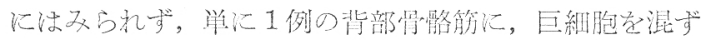
る肉芽腫様喿が浔められたに止京った。

\section{III. 考察}

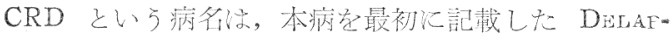

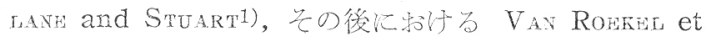

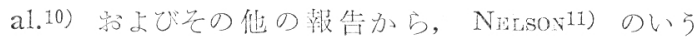
Coryza II，执よび他の著者らがしばしば CRD と同義 語的に用いる Air-sac infection 岁るいは Air-sac

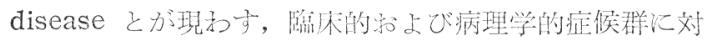
して与光られたものであり, 多数の原园学的研究によれ ば。病因に括いて P PLO と密接な閔係に立つ病である と理解される。

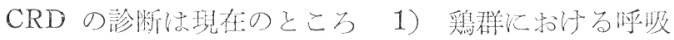
器疾患の発本状沇；2）病熖の現方与胢吸器症状，と

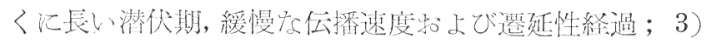

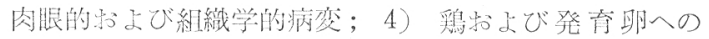

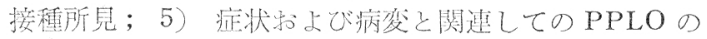

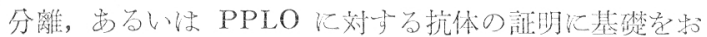
いている．以下各項について診断の基隻とす心゙きところ 学さぐってみたい。

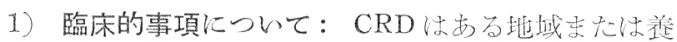

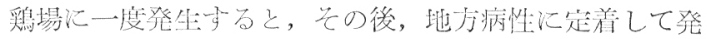

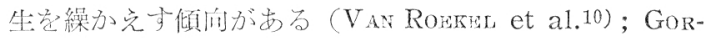

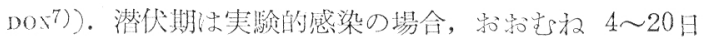
である (Delaplane and Stuart1); Van Rourel et al.10); Gordon7)). 病の経過は長く, 大部分は20日以 上， 2 力月に尔よび (Diraplane and Stuart1); Jorisson,4); FA匹̈LY and CRAWLey 12$)$ ), 時には3〜4 力 月に達するものるめる。この間，緒言に記載したような

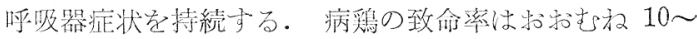
$30 \%$ であり，発生㖶群に和ける伝播速度は緩徐である。

2) 病理学的所見について：VAN ROWKaL et al.10)

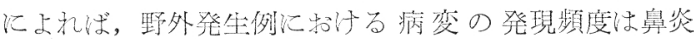
$40 \%$, 下眼罢洞炎 $33 \%$, 喉頭炎 $82 \%$ ，気管炎 $97 \%$, 気 管支炎 $21 \%$ ，肺炎 $13 \%$ ，気囊炎 $41 \%$ である病変の性 筫と程度忹非特異的であって，伝染性気管支炎とニュー カッスル病のそれから区別できず，正確な䛦断は発生状 沉，発育卵化よる病原分離和よび熖に対与る接種成績と

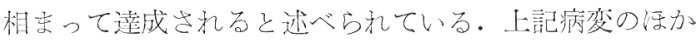

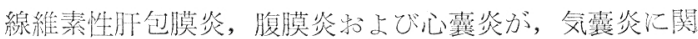
連してしばしば出現することが一般に認かられている (Cover and Walmiris); Martinezz); Gross13)).

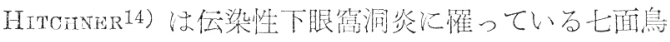
の洞壁において，明膫なりンパ泒胞あるいはリンパ小節

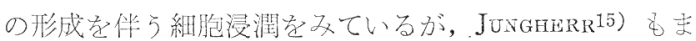
た類似の所見学破認乙, その骖断的意義学強調した。その

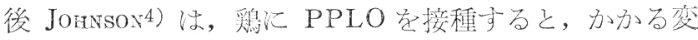
化がーでに 7 日目に気囊，肺㧍よび気管に出現すること を認め，骖断上意義ある变化と看做した。 JUNGrieRR et al.16) はニュ一カッスル病，伝染性気管支炎扣よびCRD

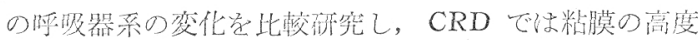
の肥厚，粘液腺の管状延長和上び上支細胞の水腄性变性

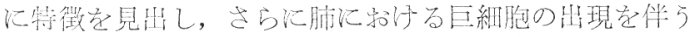
グラスローム形成结，アスペルギルス病学除けぼ，本病

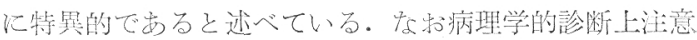

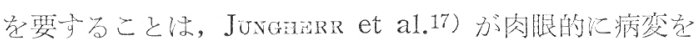
認め得存い䣋 130 例中，組織学的には，その $42.5 \%$ に 気管病変老, $11.7 \%$ 飞は肺病变觉確的得て, CRD 病恋 の肉眼的観察の不確実性を指摘している点である。

3) 鷂扎よび発育卵への接種所見につんて: 病畄の

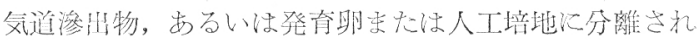

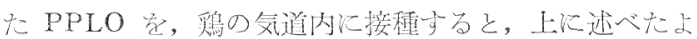
らな潜伏期の後に発症与を。このことは DefapLANA and STUART1）の哃告以来，多数の研究者により追試喟

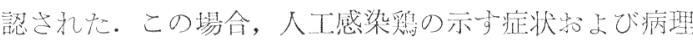
解剖的変化は，接程された熖の年令缷よび接程ルートに

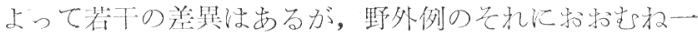

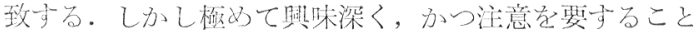
は，野外例にしばしばタられるよらな垂篤な病，乙くに

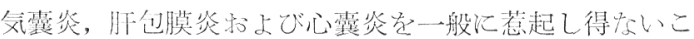
とである。

七面点の下眼简洞内への接種孔, 骖断の日的に好えで 用いられる。なぜならば，七面鳥の伝染性下眼墕洞炎の 
病原と，CRD のそれとが同一，もしくは極めて近縁な ものであることが, 各種抗生物質に対する抵抗性 (GRoss and Jorisson ${ }^{18)}$ ), 血清学的拈よび生物学的性状から (GIANFORTE et al.19)) 認められて扮り，また下眼简洞 炎と CRD とからそれぞれ採取された病的材料, あるい は分離された PPLO には，七面鳥あるいは鵎に対する 相互感染性ない乙起病性に拈いて, (DHLAPLANE20)21); Prier et al.22); Hitchner ${ }^{14}$ ); Jungherr ${ }^{15)}$; JohNson3)4); VAN Roerere et al.10); Grumbress et al.23)),

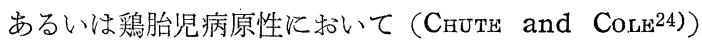
ほとんど差異が認められないからである。

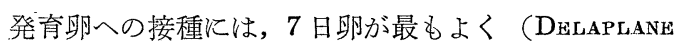
20); $\mathrm{V}_{\mathrm{AN}}$ RoGKEL et al.10)), 卵黄囊内接種で, 胎児は 24 時間後より稃化時までにわたって，極めて不規則な 死に方を示すが，この死に方が特徴視されている(VAN Roezel et al.10); Chute and Cole24); FaHey and $\left.\mathrm{C}_{\mathrm{RAWLAY}}{ }^{25}\right)$ ). 胎児には発育不良, 浮腫, 充出血, 漿尿 膜の白色限局栄, 肝抒よび腎の腫大と壞死栄がみられる が, とくに卵畞後期のものには関節附近の膿瘍, あるい はグラヌローム形成, 並びにチーズ様渗出物凝塊の出現 を伴 万気管, 気管支扣よび気囊の炎症が 観察される. VAN RoEKEL et al.10) はこれらの変化汇診断的な特異 性を与えた. CнUт世 and CoLE24) は接種後 2 7 日で死 んだ胎児は，PPLO 感染に基く充血，出血㘧よび浮腫 を, 8〜14 日で死んだものには動脈周团炎, 動脈炎拉よ び静脈周囲炎の如き血管变化, リンパ球集簇栄特よび肉 芽腫様結節が特徴的に出現すると記載している.

4） PPLOの分離について：CRD の原因は尔扮確 立されて招らない。初期の研究では Psittacosis 様 (Groupe and $\mathrm{WINN}_{\mathrm{IN}}^{26)}$ ), あるいは Rickettsia 様 (HTtChNer ${ }^{14)}$ ； Johnson ${ }^{3}$ )) と記載された微生物が原因 と考光られ, Defaplane and Stuart1), Dheaplane20) 拉よび V V RoEKer et al.10) とよってはウイルスがそ の原因に帰せられた。1952 年にいたり МARKнAM and Wong 27 ) 飞より, 次いで OLesIUK and VAN ROEKaL ${ }^{28)}$ Worg and JAMES ${ }^{29)}$ Kよって, 発育卵の継代から人工 培地倍養可能な微生物が認められ, それが PPLO に 属するものであることが示唆され，その接種によって野． 外例類似の病が作られることが示された。 その後 CRD とPPLO との関係については多数の研究がなされ, そ の結果, 本菌の鵎拈よび七面鳥に対する起病性, 舀胎児 病原性, $\mathrm{CRD}$ 病変と関連して本菌が湟とんど毎常証明 されること，执よび本菌に対する血清反応と臨床症状の 消長との間関連が存在する (FAHEX and C などの点から，CRD の病因に执いて PPLO が本質的 な役割を演ずるものであろうと，一般認められるにい たった．これより先, NeLson11,30-35) は 1933 年から 1938 年にわたって, 鷄の Coryza について広範な研究
を行い，それを 3 型に分類した．その第 2 型である長い 潜伏期と慢性経過を示す Coryza の原因として, Coccobacilliform Bodies なるものを記載した. この菌はそ の後 SMITH et al.36) により研究され，PPLO 飞属する ものであることが明らかにされた。ささらに最近にいたり FAHEY and CRAWLeY 37 ) 抢よび AdLeR and YamamoTO38) は, PPLO を以て NELSON の報告を追試し, こ れを確認した.これらの成績から, NeLson の Coryza II は現在の CRD と密接な関係に立つるのとみられる。

しかしながら，前述の如く PPLO のみの接種では， 野外例にみられるような重篤な病変, とくに気囊炎, 線

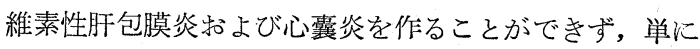
CRD 症候群の一部と認むべき NELSON の Coryza II に一致する病を起し得るに過ぎない。さらに PPLOは 一見, 健康な鷄あるいは他の疾患に䍜ている鷄からもま れならず分離される (FAHEY and CRAWLïY 25 ); EISSA 39)).このようなことから PPLOは CRD の病因におい て主導的な役割を演じ，とくに慢性化の主要因子をなす が (CRAWLEY and $\left.F_{A A H Y} 40\right)$ ), さらに他の病因群が共 働的に作用すると考兵る著者が多くなった．その 2 次的 病因群として FAHEY and CRAWLEY 41 ) 招よび JoHNSON and Domermuth6) は一種のウイルスをあげ，WASSERMAN et al.42) は Air-sac infection には, 極めてしばし ば Coli-aerogenes group の細菌が，まれにブドウ球菌 が関係していること，また伝染性気管支炎やニューカッ スル病によってもAir-sac infection が起り得ることを 明らかにして，そのすべてをCRD に帰することの誤り を指摘し，GRoss13) は Escherichia coli は単独で鵎の 気囊内に接種されても, 心囊炎, 肝包膜炎, 気囊炎, 卵 管炎あるいはブドウ膜炎を起すが，PPLO を同時に接 種する時はその病原性を著しく增強することを実験して いる. Cover and $\left.\mathrm{W}_{\mathrm{ALLER}}{ }^{5}\right)$ はコクシジゥム症, 伝染 性気管支炎を, MARTINEZ 2 快寒冷, 予防注射の反応, 他疾患あるいは産卵開始のよ5な生理的機能を，JUNGHERR et al.16) 特よび LECCE and SPERLING43) もまた, なにかある Stress 要团の作用を想定している.

病因の問題に関連して, JUNGHERR et al.16) は由来を 異にする PPLO 株飞, 血球凝集阻止反応と生物学的性 状に执いて差異を認め得ないことから，Asterococcus avis なる名称を提案し, JUNGHERR et al.44) は CRD と いらょうな総括的病名の不合理性を指摘し, PPLOのみ による鷄疫に Avian asterococcosis なる病名を示唆 し, FAHEY and CraWley 25 ) coryza と呼ぶべきことを提唱しているが，上述の理由 に鑑みて，CRD の表現する実体とは明瞭に区別されな ければならない。

以上の如く CRD の病因に関しては, 今後さらに広 範な研究が行われなければならない。しかしながら診断

日獣会誌 11 (1958) 
という実際的な問題においては LECCE and SPerLING43) がいうよ5に，PPLO の証明は大きな意義をもつもの である. 一方, CRAWLWY and FAHEY40) が述べる如く “実際的には CRD のすべての臨床例は PPLO 感染を 伴っているが，その逆は必ずしも真ではない”ことが 忘れられてはならない。

上に述べたところから明らかであるように，CRD の 原因がな扮確立されて抢らぬために，その診断はやや迁 遠とも思われる上記各項についての検討を了した上で, 総合的に慎重に下されなければならない，私どもが経験 した二養鵎場に括ける鷄疫は，本質的な点で各項に全く 一致し，それが CRD にほかならぬことが確認されたわ 村である。

わが国に特いて CRD の流行例が確認されたことは, アメリカ怙よびカナダに括ける本病による経済的損失に 鑑みて, 極めて注目を要するところであって, 本病に対 する研究の重要性が痛感される次第である.

\section{IV. 摘 要}

東京および大阪の各一養鵎場に流行した鵎疫につい て，野外発生例に対する検索成績並びに鵎扣よび発育卵 への接種成績が, 臨床一病理学的所見を中心として述べ られた.

本病はその発生状況, 臨床的症状, 病理解剖的所見, 鵎叔よび発育卵への接種所見, および PPLO の分離成 績から CRD に一致するものであることが確認された。

CRD の診断は，その原因がな拈確立されて扔らぬた め, 総合的な判定に 待たねばならない。かかる理由か ら, 診断の基準とせらるべき諸点がやや詳細に討議され た。

\section{文献}

1) DELAPLANE, J.P. and STUART, H.O.: Am.J.Vet. Res., 4, 325 (1943). 2) MARTINEZ, C.R.: O.T.E. Bubletin, 46, 170 (1956). 3) JOHNSON, E.P.: Broiler Grower, 2,12 (1951) [VAN ROEKEL et al.: Am. J. Vet. Res., 13, 252 (1952)]. 4) JOHNSON, E.P.: Cornell Vet., 44,230(1954). 5) COVER, M.S. and WALLER, E.F.: Am.J.Vet.Res., 15,119(1954). 6) JOHNSON, E.P. and DOMERMUTH, C.H.: Cornell Vet., 46, 409 (1956). 7) GORDON, R.F.: Vet. Rec., 68,547(1956). 8) WHITE-STEVENS, R. and ZEIBEL, H.G.: Poult. Sci., 33, 1164 (1954). 9) FAHEY, J.E.: Poult. Sci., 34, 397 (1955). 10) VAN ROEKEL. H., OLESIUK, O.M. and PECK, H.A.: $\mathrm{A} m$. J. Vet. Res., 13, 252 (1952).

11) NELSON, J.B.: J. Exp. Med., 59, 297 (1933). 12) FAHEY, J.E. and CRAWLEY, J.F.: Canadian J. Comp. Med. and Vet. Sci., 18,264(1954). 13) GROSS, W.B.: Poult. Sci., 35, 765 (1956). 14) HITCHNER, S.B.: Ibid., 38, 106 (1949). 15) JUNGHERR, E.L.: Am. J. Vet. Res., 10,372 (1949). 16) LUGINBUHL, R. E., and JACOBS, R. E.: Proc. Book, Am. Vet. Med. Ass., 90th Ann. Meet., P p. 303-311 (1953). 17) -., PEREIRA, Y. V. and TOURTEllotTe, M.: Proc. 27th Ann. Pull. Conf. of Lab. Workers (1955). 18) GROSS, W. B. and JOHNSON, E.P.: Poult. Sci., 32, 260 (1953). 19) GIANFORTE, E,M., JUNGHERR E.L. and JACOBS, R.E.: Ibid., 34, 662
(1955). 20) DELAPLANE, J.P.: Cornell Vet., 38, 192 (1948). 21) .: Proc. 22nd Ann. Pull. Conf. of Lab. Workers (1950). 22) PRIER, J.E., SUTHERLAND, A. K. and BEAMER, P.D.: Cornell Vet., 38, 208 (1948). 23) GRUMBLES, L.C., BONEY, W.A., Jr. and DELAPLANE, J.P.: Poult. Sci., 31,809 (1952). 24) CHUTE, H.L. and COLE, C. R.: Am. J.Vet. Res., 15, 108 (1954). 25) FAHEY, J.E. and CRAWLEY, J. F.: Canadian J. Comp. Med. and Vet. Sci., 20,7 (1956). 26) GROUPE, V. and WINN, J. D.: J. Bact., 57,515(1949). 27) MARKHAM,F.S. and WONG, S.C.: Poult. Sci., 31, 902 (1952). 28) OLESIUK, O.M. and VAN ROEKEL, H.: Proc. 24th Ann. Pull. Conf. of Lab. Workers (1952). 29) WONG, S.C. and JAMES, C.G.: Poult. Sci., 32, 589 (1953). $3_{0}$ ) NELSON, J.B.: J. Exp. Med., 58, 289 (1933).

31) NELSON, J.B.: Ibid., 63, 509 (1936). 32) Ibid., 63, 515 (1936). 33) —_.: Ibid., 64, 749(1936). 34) . : Ibid., 64,759 (1936). 35) - : Ibid., 67, 847 (1938). 36) SMITH, W.E., HILLIER, J. and MUDD, S.: J. Bact., 56, 589 (1948). 37) FAHEY, J.E. and CRAWLEY, J.F.: Canadian J. Comp. Med. and Vet. Sci., 19, 53 (1955). 38) ADLER, H.E. and YAMAMOTO, R.: Cornell Vet., 46, 337 (1956). 39) EISSA, Y.M.: O.T.E. Bulletin, 46,170 (1956). 40) CRAWLEY, J. F. and FAHEY, J. E.: Poutt. Sci., 34, 707 (1955).

41) FAHEY, J.E. and CRAWLEY, J.F.: Canadian $J$. Comp. Med. and Vet. Sci.,18, 13 (1954). 42) WASSERMAN. B., YATES, V.T. and FRY, D.E.: Poult. Sci., 33, 622(1954). 43) LECCE, J.G. and SPERLING, F.G.; Cornell Vet., 44, 441 (1954). 44) JUNGHERR, E. L., LUGINBUHL, R. E., TOURTEllotTe, M. and BURR, W. E.: Proc. Book, Am. Vet. Med. Ass., 92nd Ann. Meet., Pp. 315-321 (1955).

\section{鳥類のブルセラ病}

家禽および野生の鳥類のブルセラ病はかなり広く蔓延 している病気のように思われる.家禽の中では珠䳕が最 もかかりやすい. 3 種類のブルセラ菌のすべてによって 発病するが, Br. melitensis が他の二者よりも幾分病原 性が高い。感染は消化管より起る。

一般に感染しても症状が現われないことが多いが，時 に症状を示すこともある。しかしほとんどすべての感染 例では，幾分消耗し，産卵率も低下寸る。感染例では30 日のうちに細菌はいなくなり, ある程度の免疫を獲得す る.

病理学的変化の認められる例では, 肝, 脾, 心, 肺の 壊死と变性が存在している.

診断は凝集反応によるが, 凝集素は感染後 3 力月半ま で証明される。(ANCZYKOWSKI, F.：Med. Vet. Varsovie (1956-57)-Vet.Bull.27,512,1957)

\section{鶏コクシジウム症のサルファメサジンと オーレオマイシンの併用療法}

コクシジウム症治療の際, サルファメサジン投与によ って起る成長抑制を相殺するために, 成長促進効果のあ るオーレオマイシン投与の効果を検討した。

Eimeria tenella 感染症にサルファメサジンとともに, オーレオマイシンを投与したところ, 病状は軽減し, 成 長剤を投与しない正常対照群よりも成長が促進された。 オーレオマイシン $(200 \mathrm{~g} /$ トン $)$ のみでも死亡率を下げ 成長を促進することができた。(GARDINER, J.L. : Poult. Sci. 36,159, 1957-Vet.Bull.27, 518, 1957) 